\title{
産地の違いによる有機栽培トマトの成分
}

\section{Comparative Studies on the Constitution of Tomatoes from Organic Cultivation in Four Locations}

\author{
高澤まき子・保井 明子 \\ (仙台白百合短期大学) \\ Makiko Takazawa, Akiko Yasui \\ Sendai Shirayuri Junior College, 6-1, Honda-cho, Izumi-ku Sendai-shi, Miyagi, 981-3107 \\ 干981-3107 宮城県仙台市泉区本田町 6-1 \\ Tomato plants from organic cultivation were cultured in four productions using the \\ same fertilizing conditions and cultivating methods. An investigation was conducted to \\ determine how climatic conditions and chemical composition of the soil affect the compo- \\ nents of the tomato fruits. Between 40 to 44 tomato plants were harvested in the four \\ productions, based on their red color. The samples that were harvested in the Groduc- \\ tion had the highest in color test, rating and rapidly ripened. In the four productions, the \\ contents of total ash and calcium in the tomato fruits were the highest in the G produc- \\ tion, and phosphorus was the highest in the $\mathrm{G}$ and I prodctions. Their were affected by \\ the amounts of various available nutrients in the soil. The content of vitamin $\mathrm{C}$ in all \\ production's tomato fruits were higher than the listed value of that component in foods. \\ These were found to be available in organic cultivation. It was affected by the soil compo- \\ nents especially for calcium, nitrous acid and the full ripeness of the tomato plants, which \\ were not affected by the climatic conditions.
}

\section{1. 緒言}

作物の品質は, 八ウス栽培, 露地栽培, また有機栽培 や普通栽培による施肥条件の違い, さらに収穫時期や気 候条件などの多くの要因で左右される. また, 品種や産 地によっては作物の成分に違いがあることが報告1) 4)さ れている.しかし, 産地によって成分上に違いがみられ るといっても, 促成栽培, 八ウス栽培などの様々な栽培 方法で収穫されたものであり, また同一の施肥条件で行 ったものではない.

そこで, 今回は 4 つ有機栽培地区に依頼し, 同じ完 熟堆肥を用いて施肥条件, 栽培方法を同一にしてトマト を生育し, 収穫されたトマト果実の成分を測定して,
産地間の有機栽培トマト果実の成分の比較を行った。ま たそのトマト果実成分と気候条件や土䁃中の化学成分上 の結果からも考察を加えた。

\section{2. 実験方法}

\section{（1）トマトの生産地}

トマトの生産地は，宮城県岩沼市（以下M区と略す.)， 茨城県八郷町（以下 I 区と略す.), 東京都立川市（以下 T区と略す.)，岐阜県大野郡（以下 G区と略す.）の 4 地区である.これらの 4 地区はすでに 10 年以上も前から 有機栽培に切り替えているところである，固場の大きさ は，特に統一はしていないので栽培本数は異なった。 


\section{(2) 肥料および土壤分析}

肥料は牛糞，木の皮，米糠を主原料とした市販の完熟 堆肥（飛騨応用資材侑製）を全地区に用いた。土壌と完 熟堆肥の化学成分の分析については, エーザイ生科研セ ンターに依頼した。 土壌は各畧の対角上から 5 力所採取 し混合させたものを分析に供した．また依頼先の分析值 に記されているトマト栽培における標準施肥設計值 ${ }^{5)}$ に, 完熟堆肥に含まれる窒素量から今回の施肥量を算出 し, 各地区の施肥量は $7 \mathrm{t} / 10 \mathrm{a}$ に統一した。

\section{（3）栽培方法および試料，気候}

トマトは各地区において, 露地栽培法により栽培管理 し生育させた，今回はトマト果実の収穫をでに十分に生 育できる施肥量なので追肥は行わず元肥のみとした，ま た，栽培中の灌水においても行わなかった．灌水を行う 必要が無いように各地区の圃場には土壤中の水分蒸発を 防ぐために十分な葟を敷いた。

試料の品種は大型福寿を使用し, 収穫したトマト果実 は第 1 果房であり, 熟度の違いによって成分が異なること から開花日から40４5日程度経ったものとして日数で各 地区の収穫を統一した．これは熟度吕（70９0\%着色） ${ }^{6}$ に相当する．つまり全体的に赤味が均一的になり，へた の部分がわずかに青みがかっている状態で収穫し，それ を直ちに送ってもらい，その中で大きさに差がないもの 各地区 5 個選び実験用試料とした.

各地区の苗の定植日, 果実の収檴日, 開花日加ら収穫 日までの日数を表 1 に示した. 苗の定植日はM区，I区， $\mathrm{T}$ 区が 5 月下旬から 6 月上旬で， $\mathrm{G}$ 区は 7 月上旬であっ た. 従って，収穫日もM区，I区，T区が 8 月中であり， G区は 9 月中旬とずれ込んだ.

栽培期の気候状態は，4 月から 9 月までの月々の平均 気温, 降水量, 日照時間について, それぞれの地区に最 も近い気象庁または気象台で観測されたデータを収集し た. その気候状態について，表 2 に示した.

今回の実験においては灌水を行わなかったので, 各産 地の定植期から収穫期までの降水量が関与してくる.
表 24 生産地の気候状態

\begin{tabular}{cccc}
\hline 生産地 & $\begin{array}{c}\text { 日照時間 } \\
(\mathrm{h}) / 3 \text { 力月 }\end{array}$ & $\begin{array}{l}\text { 降水量 } \\
(\mathrm{mm}) / 3 \text { 力月 }\end{array}$ & $\begin{array}{l}\text { 平均気温 } \\
\left({ }^{\circ} \mathrm{C}\right) / 3 \text { 力 }\end{array}$ \\
\hline $\mathrm{M}$ 区 & 467 & 387 & 21.3 \\
$\mathrm{I}$ 区 & 462 & 563 & 22.4 \\
$\mathrm{~T}$ 区 & 454 & 502 & 23.4 \\
$\mathrm{G} 区$ & 540 & 469 & 22.2 \\
\hline
\end{tabular}

日照時問，降水量：M, I, T 区は $5 \sim 8$ 月までの, G区は $6 \sim 9$ 月までの累積値

平均気温 : M, I, T区は $5 \sim 8$ 月までの, $\mathrm{G} 区 は ~ 6 \sim 9$ 月までの 平均值

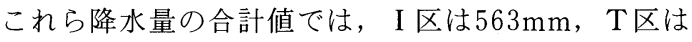
$502 \mathrm{~mm}$ ，G区は $469 \mathrm{~mm} ， \mathrm{M} 区 は 387 \mathrm{~mm}$ の順であり，M 区が最も少ない值であった。また，産地毎の日照時間の 合計值ではT区は454時間，I区は462時間，M区は467 時間，G区は540時間であり，G区は最も日照時間が多 かった。

定植から収穫期までの各産地の 3 力月平均気温では, T区が 4 地区の中では, 高い気温であった．次いて I 区 であり，G区とM区はほぼ同じような気温であった，以 上の結果をもとにトマト果実中の成分と考察を行った.

\section{(4) 測定方法}

1) 色調一定の日数で収穫したトマト果実は産 地によって熟度にどの程度違いがあるかを色調で調べ た。すなわち，トマト果実をホモジナイズしペースト状 にしたものを, 測色色差計（日本電色工業秼製1001 DP 型）を用い, $\mathrm{L}$ (明度), $\mathrm{a}$ (赤味度), $\mathrm{b}$ (黄味度) 值を 測定した.

2) 水分および兏分 $ト$ マト果実の水分は $80^{\circ} \mathrm{C}$ の 常圧加熱㲦燥法7), 灰分は直接灰化法7) により含量を求 めた.

3） Ca, Mg およびP トマト果実を乾式灰化後, 塩酸で溶解して試料溶液とし, カルシウムとマグネシウ ムはキレート滴定法7)により, リンはモリブデン青比色 法8)により測定した。

4 ）ビタミンC トマト果実のビタミンCはヒド

表 1 トマト定植日, 収穫日, 開花日から収穫までの日数, トマト果実の色調および熟度

\begin{tabular}{|c|c|c|c|c|c|c|c|}
\hline 生産地 & 定植日 & 収穫日 & $\begin{array}{l}\text { 開花日から } \\
\text { 取穫日までの日数 }\end{array}$ & L (明度) & $\begin{array}{l}\text { 調 } \\
\mathrm{a} \text { (赤味度) }\end{array}$ & b （黄味度） & 熟度*) \\
\hline M区 & $5 / 31$ & $8 / 5$ & 44日 & 28.0 & 23.3 & 17.6 & 3.5 \\
\hline I 区 & $5 / 27$ & $8 / 20$ & 40日 & 20.9 & 31.2 & 16.6 & 4.5 \\
\hline T区 & $6 / 3$ & $8 / 22$ & 40日 & 26.3 & 16.4 & 16.8 & 2.5 \\
\hline G区 & $7 / 9$ & $9 / 14$ & 44日 & 21.6 & 32.3 & 14.9 & 5.0 \\
\hline
\end{tabular}

*)東尾ら ${ }^{11)}$ による a 值からの熟度区分結果で照合させた数值 
ラジン法9)により，総ビタミンC 量を測定した

5) $\mathrm{pH}$ および糖度 トマト果実の $\mathrm{pH}$ はガラス電 極 $\mathrm{pH}$ メーター（東亜電波工業侏製 $\mathrm{HM}$ - $11 \mathrm{P}$ 型）を 用い, 糖度はアタゴ屈折糖度計（N 1 型）を用いて測定 した.

6 ）還元糖 トマト果実の還元糖量はソモギーネ ルソン法 ${ }^{10)} に よ り$ 測定した.

\section{3．結果および考察}

\section{（1）トマト果実の色調}

各地区のトマト果実の色調について表 1 に示した．赤 色系のトマト果実の成熟度は $\mathrm{a}$ 值で評価されている11). 東尾ら ${ }^{11)}$ の熟度区分と a 值との関係の結果から，本実験 の $\mathrm{a}$ 值の結果と照らし合わせてみると, 表 2 に示した日 照時間が最も多かった $\mathrm{G}$ 区は $32.2 て ゙$ 最も高い值を示し， 熟度区分は 5 に值し成熟度が最も大きかった。降水量の 最も多かった I 区は31.2であり熟度区分 4.5 に相当し， 平均気温が最も低くしかも降水量の最も少なかった M区

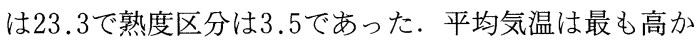
ったが日照時間は最も低かったT区は，16.4と低い值で あり，熟度区分は 2.5 に相当し，だいだい色に近い赤味 を呈しているトマト果実で，4 産地の中では熟度が低か った.

これらのことから, 試料に供したトマトの熟度は, 収 穫日数がほぼ一定であっても各産地の気温や降水量の違 いよりも，日照時間の違いによる影響が大きく熟し方が 異なった. 特にG区のトマト果実の熟度が高かったこと

\section{表 34 生産地のトマト果実の成分}

\begin{tabular}{cllcccccc}
\hline 生産地 & $\begin{array}{l}\text { 水分 } \\
(\%)\end{array}$ & $\begin{array}{l}\text { 灰分 } \\
(\mathrm{g})\end{array}$ & $\begin{array}{c}\mathrm{Ca} \\
(\mathrm{mg})\end{array}$ & $\begin{array}{r}\mathrm{Mg} \\
(\mathrm{mg})\end{array}$ & $\begin{array}{c}\mathrm{P} \\
(\mathrm{mg})\end{array}$ & $\begin{array}{c}\text { 総ビタミンC 含量 } \\
(\mathrm{mg})\end{array}$ & $\begin{array}{c}\text { 桾度 } \\
(\%)\end{array}$ & $\begin{array}{c}\text { 還元糖 } \\
(\mathrm{mg})\end{array}$ \\
\hline $\mathrm{M} 区$ & 93.1 & 0.55 & 7.2 & 8.8 & $37.1^{* *}$ & 25.9 & 5.6 & 2.6 \\
$\mathrm{I} 区$ & 93.9 & 0.48 & 6.0 & 10.4 & 21.6 & $31.6^{*}$ & 5.1 & 3.2 \\
$\mathrm{~T} 区$ & 94.6 & 0.42 & 5.7 & 8.6 & 17.3 & 27.2 & 4.4 & 2.3 \\
$\mathrm{G} 区$ & 94.2 & $0.60^{*}$ & $14.3^{* *}$ & 8.6 & $37.1^{* *}$ & $20.0^{* *}$ & 5.2 & 2.6 \\
\hline 食品成分表值 & 94.0 & 0.5 & 7 & 9 & 26 & 15 & - & - \\
\hline
\end{tabular}

$*: \mathrm{p}<0.05,{ }^{* *}: \mathrm{p}<0.01$

表 4 トマト生産地土壤の有効態養分含量, リン酸吸収係数 $\quad(100 \mathrm{~g}$ 中）

\begin{tabular}{|c|c|c|c|c|c|c|}
\hline 生産地 & $\begin{array}{c}\text { 硝酸態窒素 } \\
(\mathrm{mg})\end{array}$ & $\begin{array}{c}\text { カルシウム } \\
(\mathrm{mg})\end{array}$ & $\begin{array}{c}\text { マグネシウム } \\
\text { (mg) }\end{array}$ & $\begin{array}{c}\text { カリウム } \\
(\mathrm{mg})\end{array}$ & $\begin{array}{l}\text { リン酸 } \\
(\mathrm{mg})\end{array}$ & リン酸吸収係数 \\
\hline M 区 & 1.55 & 135.4 & 28.6 & 54.4 & 21.4 & 390 \\
\hline I 区 & 3.56 & 224.5 & 44.8 & 108.9 & 7.8 & 1780 \\
\hline $\mathrm{T}$ 区 & 1.83 & 347.5 & 30.4 & 49.6 & 2.9 & 1910 \\
\hline G 区 & 10.32 & 356.1 & 60.9 & 110.2 & 88.1 & 320 \\
\hline 標準値 & $0.7 \sim 3.5$ & $200 \sim 400$ & $35 \sim 70$ & $15 \sim 40$ & $20 \sim 60$ & $500 \sim 800$ \\
\hline
\end{tabular}

は日照時間が長かったことがひとつの要因と思われた。

（2）トマト果実の水分，灰分，無機成分および $\mathrm{pH}$

(1) 水分含量 トマ卜果実の水分含量を表 3 に示し た. トマト果実の各産地の水分含量は93.1 94.6\%であ り, 食品成分表值 ${ }^{12)}$ に示されている水分含量の $94 \%$ とほ ぼ一致し，産地による差は認められず，表 3 に示した各 産地の降水量の多少の影響はないと思われた.

(2) 灰分含量 トマト果実の灰分含量を表 3 に示し た. 灰分含量が最も高かったのは G区 $0.60 \mathrm{~g}$, 次いでM 区 $0.55 \mathrm{~g}$ であり， I 区は $0.48 \mathrm{~g} ， \mathrm{~T}$ 区は $0.42 \mathrm{~g}$ で後者 2 地区は食品成分表值 ${ }^{12)}$ の $0.5 \mathrm{~g}$ より低い值であった， G 区が灰分含量の最も高かった要因は 4 産地の中で $\mathrm{G}$ 区は 表 4 に示した土壌中の有効態養分の值が高く, 硝酸態窒 素の值が非常に高く標準值を上回っており，肥沃な土壤 であったためと思われた.

逆に灰分含量の少ない I 区，T区はリン酸吸収係数が 非常に高く, 土壌中の有効態リン酸量の低值が灰分含量 に影響したものと思われた，本実験において，土壤中の 有効態化学成分含量がトマト果実の灰分に与える影響は 大きいものと思われた.

(3) カルシウム含量 トマト果実のカルシウム含量 を表 3 に示した. カルシウム含量においても $\mathrm{G}$ 区が $14.3 \mathrm{mg}$ と最も高い値を示した。これは食品成分表值 ${ }^{12)}$ の $7 \mathrm{mg}$ よりも 2 倍の值を示し有意差が認められた。M 区は $7.2 \mathrm{mg}$ で食品成分表值 ${ }^{12)}$ と同等であるが，I 区は $6.0 \mathrm{mg}$ ，T区は $5.7 \mathrm{mg}$ でそれより低值であった．今回 の結果からは各産地間のトマト果実中のカルシウム含量 と土壤中のカルシウム含量と の相関性はみられなかった。

(4) マグネシウム含量

トマト果実のマグネシウム 含量を表 3 に示したＩＩ品 $10.4 \mathrm{mg}$ と最も高い值を示し たが，T区は $8.6 \mathrm{mg} ， \mathrm{G}$ 区は $8.6 \mathrm{mg}$, M区は $8.8 \mathrm{mg}$ と 3 産地はほぼ同含量であり食品 成分表值 ${ }^{12)} 9 \mathrm{mg}$ 之同程度で あった。このマグネシウム含 量では産地間の有意差は認め られず，また土壌中のマグネ シウム含量がトマト果実中の マグネシウム含量に影響する ということはなかった。 
(5) リン含量 トマト果実のリン含量を表 3 に示し た. M区と G区が31.7mg であり非常に高い值を示した が，T区は17.3mg，I 区は21.6mg で食品成分表値12) の26mg より低い值を示した．このT区，I区の低い結 果は, 関東ローム層が分布している火山灰土壌の影響に よるものと思われた，つまり T区と I 区は関東ローム層 の中に位置し,肥料に含まれるリン酸は土壌に吸着され, 作物に吸収しにくくなるという火山灰土猿の特徴5)を持 っている圃場である。 その分析の結果, 土壤中の化学成 分上のリン酸四収係数が非常に高く, 有効態リン酸は低 い值になっており，この土壤の特徵がトマト果実中のリ ン含量に影響したものと思われた。

(6) $\mathrm{pH} \quad$ トマト果実の $\mathrm{pH}$ に扔いては，特に表に 示さないが4.1〜4.4の範囲にありこの差は未熟なもの程 $\mathrm{pH}$ が低く, 産地間の差というよりは熟度の差によるも のと思われた。

（3）糖度，還元糖および総ビタミンC

トマト果実の糖度, 還元糖量, 総ビタミンC 含量を表 3 に示した. 総ビタミンC 含量では I 区が $31.6 \mathrm{mg}$ と最 も高い值であり，次いでT区の $27.2 \mathrm{mg}, \mathrm{M}$ 区の $25.9 \mathrm{mg}$, G区の $20 \mathrm{mg}$ で産地によって違いがみられた。

全ての地区の值は食品成分表值 ${ }^{22}$ に比較し高い值であ り，有機栽培による効果とも考えられ，それと合わせて 八ウス栽培や促成栽培のトマト果実よりも直射日光6)を 十分に浴びた自然栽培のものの方がビタミンC含量は高 いことに一致した。

また, 土壌中のカリウム含量が高い場合や灌水量を減 らした場合には, 糖やビタミンC含量が高くなり, 逆に 土壤中の硝酸含量が高ければ高いほどビタミンC 含量は 減少する13,14) といわれている，これらのことから，I区 のトマト果実ビタミンC含量が最も高かったのは, 土壤 中のカリウム含量が高かったことが関係していると思わ れた。しかし，同様にG区の土壤中のカリウム含量が多 いにも関わらずトマト果実のビタミンC含量は最も低か った．これは土壌中の硝酸態窒素含量が標準值を非常に 上回っており，これがトマト果実中のビタミンC含量を 減少させた一原因であると思われた。

糖度においてはM区，I区，G区が5\%を越えており， 特にM区が高く，T区は $4.4 \%$ と低い值であった，還元 糖量については，I 区が最も高い值を示し，糖度の結果 と同じ傾向であった。糖は, ビタミンCの前駆物質 15) 17) として知られておりビタミン $\mathrm{C}$ と還元糖の間には 正の相関関係がみられ，食べて甘く感じればビタミンC も多い18，19）といわれている。 また糖の量も，光や灌水
の量が影響する20) 22) といわれている.

トマト果実中のビタミンC 含量と糖含量は，I 区が最 も高い値を示したが，降水量および日照時間の点から反 るとそ机らを高める気候条件ではなかった，逆にG区の 日照時間が多いという点でみると，その糖度の值は高い が，還元糖とビタミンC含量は低い值であった。このこ とから気候条件が影響しているというよりは前記したよ うに，むしろ土壌中のカリウム量や硝酸含量が高いこと がトマト果実中の糖含量やビタミンCを左右する一要因 と思われた。

また，鈴木6)によるとトマトの収檴熟度とビタミンC 含量, 糖含量の関係は, 熟度が増すにつれて, 桾含量は わずかに増加するが，ビタミンC含量は熟度の進行に伴 い熟度吕（70９0\%着色）までは増加し，熟度 N（100 \%着色）では減少傾向にある．さらには，前報23)による とトマト果実が全体的に熟度が均一でほぼ $100 \%$ 着色状 態の場合, 赤味度が高いほどビタミンC含量は低い傾向 にあった。したがって，前述の色調で記述したように $\mathrm{G}$ 区は最も赤味度が高かったことから成熟度が大きいと考 えられ，この点からもビタミンC 含量が低い要因と思わ れた。

\section{4. 要約}

4 地区の生産地を設け，施肥条件，栽培方法を同一と してトマト栽培を行いトマト果実を收穫して成分分析 し，そのトマト果実の成分を比較検討した。

1）それぞれの産地のトマト果実收檴日数は 40 から 44日の範囲にあり，収穫されたトマト果実の色調におけ

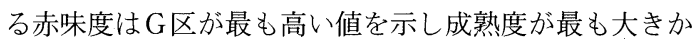
った。

2 ）産地の違いによるトマト果実の成分では，水分 に差は認められなかったが，無機成分中の灰分，カルシ

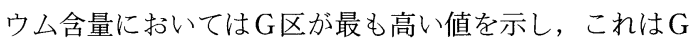
区の土壌中の有効態養分含量が高かったことに影響した と思われた.リン含量においてはM区と $\mathrm{G}$ 区が最も高く, I 区と T区が低い值を示し，産地による差が認められた。 I 区とT区のリン含量が低い要因は火山灰土壌によるリ ン酸吸收保数が高い地域であるためと考えられた。

3）トマト果実のビタミンC含量は，すべての産地 のものが食品成分表值より上回って抢り有機栽培や露地 栽培の効果と思われ，特にI 区が高くG区が低い值を示 し，差が認められたＩ区が最も高かったのは，土壤中 のカリウム含量が高かったこと，G区が最も低かったこ とは気候条件の違いよりも, 土壤中の硝酸態窒素含量が 
多かったことと成熟度が大きかったことに起因している と考えられた.

本研究にあたり, トマトの栽培, 生育管理にご協力下 さいました 4 地区の生産地の生産者の方々に深く御礼申 し上げます。

本論文の概要は, 平成13年日本家政学会, 東北·北海 道支部第46回大会において発表したことを付記する.

\section{参考文献}

1）目黒孝司，川原祥司，吉田企世子，山田次郎，下野勝昭： 消費者ニーズに応えた野菜の品質基準策定，１－30（1987）

2）木下隆雄, 穂積清之, 野中正雄 : 野菜誌報, 4, 139-144 (1977)

3）吉田企世子：財団法人エム・オー・エー健康科学センター 研究報告集 (1993)

4）吉田企世子：栄養と健康のライフサイエンス, vol. 1, No. 3 , 27-29 (1996)

5）松坂泰明, 栗原 淳監修: 土壤 - 植物栄養 - 環境辞典, 83 , 博友社（1998）

6）鈴木芳夫編：野菜栽培の基礎知識，農文協（1999）

7）小原哲二郎, 鈴木隆雄, 岩尾浩之監修 : 改訂食品分析ハン ドブック, 建帛社 (1982)

8）西郷光彦編 : 栄盖のための基礎化学実験教程, 三共出版 (1990)

9）大西正三編：要説栄養 - 食品学実験, 50, 医歯薬出版 (1986)
10）中村カホル, 滝田聖親, 渡部俊弘 : 基礎食品学実験書, 三 共出版（1994）

11）東尾久雄, 岡田邦彦, 亀野 貞 : トマト果実の成熟に伴う 果実表面色の变化, 園芸学雑誌，58，622-623（1989）

12）科学技術庁資源調査会編：五訂日本食品標準成分表 (2001)

13）吉田企世子, 山口文芳, 熊沢喜久雄 : 日本土壤肥料学会講 演要旨 (1988)

14）白杉直子, 白木洋三, 伊藤文女, 高見由紀, 山口平八郎 : 施肥量の異なる有機栽培野菜の L-アスコルビン酸/硝酸比, 日本調理科学会誌，33，4，114（2000）

15）菅原友太：農園芸作物のビタミンCに関する研究，32，養 賢堂 (1957)

16）ビタミン学編集委員会編 : ビタミン学 II，567, 東京化学 同人 (1980)

17）香川靖雄 : 新ビタミン学, 408, 日本ビタミン学会 (1980)

18）吉田企世子, 森 敏, 長谷川和久, 西沢直子, 熊沢喜久雄 : 日本栄養食糧学会誌，37，123（1984）

19）吉田企世子：調理科学, 26, 4 (1993)

20）日笠祐治, 今田成雄 : トマトの ${ }^{14} \mathrm{C}$-光合成産物の挙動に 及ぼす培地窒素濃度の影響, 日本土壌肥料学雑誌, 64,4 , 377-384 (1993)

21）馬西清憲, 上田英臣，福元康文，吉田徹志 : 灌水量の違い がトマト作物体および果実に及ぼす影響, 高知大学学術研究 報告，43，33-40（1994）

22）吉田徹志, 上田英臣, 馬西清憲, 福元康文 : トマトの生育 と果実の収量・品質に及ぼす灌水量と窒素施用量の影響, 高 知大学学術研究報告, 45, 61-68 (1996)

23）高澤まき子, 保井明子：有機栽培トマトの品質と土壤成分, 日本食生活学会誌, 10，3，36（1999） 